\title{
Türkçe Öğretmenlerinin 6. Sınıf Düzeyindeki Hazırlık Çalışmalarını Uygulama Durumları Üzerine Bir Değerlendirme
}

Hakan ISKENDER, Doktora Öğrencisi, Karadeniz Teknik Üniversitesi, Eğitim Bilimleri Enstitüsü, hiskender82@gmail.com Erhan DURUKAN, Doç. Dr., Karadeniz Teknik Üniversitesi, Fatih Eğitim Fakültesi, erhandurukan@gmail.com

Öz: Bu çalışmanın amacı, Türkçe ders kitaplarındaki hazırlık çalışmalarının uygulanma durumunu ve hazırlık çalışmalarının uygulanmasında yaşanan sorunların nedenlerini ortaya koymaktır. Araştırma nicel bir yaklaşımla desenlenmiş ve tarama modelinde yürütülmüştür. Araştırmanın örneklemini Trabzon ilinde görev yapan ve 6. sınıflarda derse giren 53 Türkçe öğretmeni oluşturmaktadır. Verilerin toplanmasında "Kişisel Bilgi Formu" ve "Türkçe Öğretmenlerinin 6. Sınıf Düzeyindeki Hazırlık Çalışmalarını Uygulama Durumu Anketi" kullanılmıştır. Elde edilen verilerin analizi için betimsel istatistik yöntemleri (frekans, yüzde, ortalama), bağımsız örneklem t-testi ve tek yönlü ANOVA kullanılmıştır. Araştırma sonunda, Türkçe öğretmenlerinin öğretmen kılavuz kitabında yer alan hazırık çalışmalarının \%37'sini tam olarak uyguladıklarını belirttikleri görülmüştür. Hazırık çalışmalarını uygulamama ya da kısmen uygulama nedenleri arasında öncelikli olarak çalışmanın fazla zaman alıcı olması gösterilmiştir. Hazırlık çalışmalarını uygulama durumunun cinsiyet, yaş, mesleki kıdem ve okulun bulunduğu yerleşim birimi değişkenine göre anlamlı düzeyde değişiklik göstermediği tespit edilmiştir.

6. sinif

Anahtar Kelimeler: Türkçe öğretmeni, öğretmen kılavuz kitabı, hazırlık çalışmaları, Türkçe dersi,

\section{An Analysis of Turkish Teachers' Implementation of $6^{\text {th }}$-grade Preparatory Activities}

\begin{abstract}
The purpose of this study is to examine the implementation of preparatory activities in Turkish course books and to reveal the causes of the problems in the completion of such activities. The research was based on a qualitative approach and survey method. The research sample consists of 53 Turkish teachers working in Province Trabzon and teaching $6^{\text {th }}$-grade students. Data was collected using a "Personal Information Form" and "Turkish Teachers' Implementation of $6^{\text {th }}$-Grade Preparatory Activities Survey" Descriptive statistical methods (frequency, percentage, average), independent samples t-test and one-way analysis of variance (ANOVA) were used in the data analysis. The research results demonstrated that the Turkish teachers thoroughly implemented $37 \%$ of preparatory activities included in the teacher's guide. The primary reason expressed by the teachers for no visible implementation or partial implementation of preparatory activities was the time-consuming nature of such activities. The research also found out that the implementation of preparatory activities did not significantly differ by variables including gender, age, professional seniority and the residential area where the school is located.
\end{abstract}

Key Words: Turkish teacher, teacher's guide book, preparatory activities, Turkish course, $6^{\text {th }}$ grade 


\section{GiRiş}

Yapılandırmacı eğitim anlayışının esas alındığı Illköğretim Türkçe (6, 7 ve 8 . Sınıflar) Dersi Öğretim Programı ile birlikte öğrencilerin öğrenme ortamlarında elde ettikleri bilgiyi etkin bir şekilde zihinsel birtakım süreçler aracılığıyla işlemesi ve zihninde yapılandırması beklenmektedir. Anlamlı bir öğrenmenin gerçekleşmesi için öğrencilerin ön bilgilerinin yeni öğrendikleriyle etkileşime girerek çeşitli zihinsel etkinlikler aracılığıyla kalıcı duruma getirilmesi gerekmektedir.

Bireyin etkin bir çaba göstermesi gereken yapılandırmacı eğitim anlayışına dayalı öğrenme ortamında birtakım öğrenme süreçlerinin varlığından söz etmek gerekir. Güneş'e (2009) göre Türkçe öğretiminin öğretme-öğrenme süreci beş aşamadan oluşmaktadır. Bunlar; hazırlık, anlama, metin aracılığıyla öğrenme, kendini ifade etme ve ölçme-değerlendirme aşamalarıdır. Bunlardan hazırlık aşaması, Onan'a (2012) göre, "Türkçenin ana dili olarak öğretiminde bilgi işleme süreci açısından özellikle önem taşımaktadır." Hazırlık çalışmaları, bu aşamada öğrenciler için yeni öğrenme alanına yönelik önemli faydalar sağlamaktadır. "Türkçe derslerinde hazırlık çalışmaları ile öğrencinin okuma, dinleme / izleme etkinliklerine hazırlanması, konuyla ilgili ön bilgilerini harekete geçirmesi, konu ya da kavramların anlaşılmasını kolaylaştırıı bilgiler edinmesi, metne motive olması hedeflenmektedir" (Örge Yaşar, 2011). Türkçe öğretimi açısından hazırlık çalışmaları, ön hazırlık ve zihinsel hazırlık olarak iki ana başlık altında ele alınmaktadır. Ön hazırlık; öğrenci ve öğretmenlerin araç gerecini hazırlaması, materyal seçmesi, sunum için gerekli nesne ve modelleri getirmesi, oturacağı yeri belirlemesi gibi etkinliklere başlamadan önce yaptığı genel hazırlıkları; zihinsel hazırlık ise ön bilgileri harekete geçirme, anahtar kelimelerle çalışma, metni tanıma ve tahmin etme, amaç, yöntem ve teknik belirleme çalışmalarını içermektedir (Güneş, 2007, s. 318). Zihinsel hazırlık çalışmalarının ilk basamağı olan ön bilgilerin harekete geçirilmesi aşaması özellikle yeni öğrenilenlerin zihinde yapılandırılması için oldukça önemlidir. Bloom'a (1998, s. 53) göre, "öğrencilerin belli bir ders veya kurstaki notu, onun bu ders ya da kurstaki öğrenmelerine dayanması gerekirken bu notun öğrencinin daha bu ders ya da kursa gelmeden önceki başarısı üzerine temellendiği görülmektedir."

Yapılandırmacı eğitim anlayışının esas alındığı öğrenme ortamlarında yeni öğrenmelerin yeterli düzeyde sağlanabilmesi için ön bilgilerin harekete geçirilmesinin ciddi bir önemi vardır. "Yapılandırmacı yaklaşıma göre yeni bilgi ve beceriler verilmeden önce öğrencilerin ön bilgilerini hatırlaması sağlanmalıdır. Böylece ön bilgiler kullanıma hazır duruma getirildikten sonra yeni öğrenmelere geçilmeli; eski ve yeni öğrenmeler arasında ilişkiler kurularak anlamlı öğrenme sağlanmalıdı" (Güneş, 2007, s. 272). Ön bilgilerin harekete geçirilmesini ve genişletilmesini sağlamanın bir yolu da öğrencilerin okul dışında ilgili öğrenme alanına yönelik gerçekleştirecekleri farkı çalışmalardır. Arslan'a (2009) göre "bilginin yapılandırılabilmesi için ön bilgilere ihtiyaç duyulmaktadır. Bu ihtiyacın karşılanabilmesi için yapılması gereken çalışmalardan birisi, derse hazırlık amacıyla dersten önce yapılan araştırmalardır."

Konuyla ilgili gerçekleştirilen araştırmalar, ön bilgilerin öğrenme üzerindeki olumlu etkilerine dikkat çekmektedir. Yanpar Şahin'in (1998) araştırmasında ilkokul 4. sınıf sosyal bilgiler ve matematik derslerinde öğrencilerin öğrenme düzeylerini yordama etkisi en güçlü değişkenin ön öğrenmeler olduğu sonucu ortaya çıkmıştır. Dochy, Segers ve Buehl (1999), 183 çalışma üzerinde gerçekleştirdikleri meta analiz sonucunda bu çalışmaların \%91,5'inde ön bilgi ve akademik başarı arasında olumlu bir ilişkinin tespit edildiğini ortaya koymuştur. MullerKalthoff ve Moller (2006) ise daha fazla ön bilgiye sahip olan üniversite öğrencilerinin daha az ön bilgiye sahip öğrencilerden olguları tespit etme ve içeriği anlama bakımından genel olarak 
daha iyi sonuçlar elde ettiklerini belirlemişlerdir. Diğer yandan Işık ve Erdem (2016), Türkçe öğretmenlerinin öğrencilerdeki ön bilgi yetersizliğini Türkçe öğretiminde (konuşma ve dil bilgisi bakımından) bir sorun olarak gördüklerini tespit etmişlerdir.

Ön bilgilerin önemine rağmen çeşitli nedenlerden dolayı öğrenciler arasında farklı düzeylerde olması, yapılandırmacı öğrenme sürecine olumsuz yönde etki eden önemli sorunlardan birisi olarak düşünülebilir. "Günümüz dünyasında öğrenciler arasında farklılıklar giderek artmaktadır. Bu durum, onların etnik kimlikleri veya dillerinden değil, ön bilgileri ve deneyimlerinin çeşitliliğinden kaynaklanmaktadır" (Fisher, Frey ve Lapp, 2010). Türkiye'de de bu tür bir çeşitliliğin var olduğu söylenebilir. Örneğin, bilgi teknolojisine erişim olanaklarından kırsaldan kente göçün getirdiği uyum sorunlarına kadar geniş bir yelpazede yaşanan sosyokültürel tabanlı farklılıklar, öğrenciler arasında ister istemez pek çok öğrenme durumuyla ilgili bir ön bilgi farklılaşması oluşturmaktadır. Ayrıca farklı ders içeriklerindeki yeni öğrenme alanlarına yönelik hazırlık çalışmalarının işlevselliklerinin de ön bilgi farklılaşması üzerinde rolü olduğu düşünülebilir.

Bu durumda, ders içeriklerindeki hazırlık çalışmalarının öğretim sürecinde ne düzeyde uygulandığının ve yeterli düzeyde uygulanamayan hazırlık çalışmalarında, bu duruma yol açan sorunların tespiti önem kazanmaktadır. Böylece hazırlık çalışmalarının daha etkili bir hâle getirilmesi hususunda önemli bir sorunun ortadan kalkabileceği düşünülebilir. Bu gerekçeyle çalışma, Türkçe ders kitaplarındaki hazırlık çalışmalarının uygulanma durumunu ve hazırlık çalışmalarının uygulanmasında yaşanan sorunların nedenlerini ortaya koymayı amaçlamaktadır. Araştırmanın bu temel problemine bağlı olarak aşağıda belirtilen alt problemlere cevap aranmıştır:

1. Türkçe öğretmenlerinin hazırlık çalışmalarını uygulama durumları ne düzeydedir?

2. Türkçe öğretmenlerinin hazırlık çalışmalarını kısmen uygulama ya da uygulamama sebepleri nelerdir?

3. Türkçe öğretmenlerinin uygulanmayan ya da kısmen uygulanan hazırlık çalışmaları yerine alternatif hazırlık çalışması uygulama durumları ne düzeydedir?

4. Türkçe öğretmenlerinin hazırlık çalışmalarını uygulama durumları ile çeşitli bağımsız değişkenler (cinsiyet, yaş, mesleki kıdem, okulun bulunduğu yerleşim birimi) arasında anlamlı farklılıklar var mıdır?

\section{YÖNTEM}

Bu bölümde araştırmanının modeline, evren ve örneklemine, veri toplama araçlarına ve verilerin nasıl analiz edildiğine değinilmiştir.

\subsection{Araştırmanın Modeli}

Bu çalışma, nicel araştırma yaklaşımına göre desenlenmiştir. Araştırmada, Türkçe öğretmenlerinin hazırlık çalışmalarını uygulama durumlarının, hazırlık çalışmalarının kısmen uygulanma ya da uygulanmamasına yol açan nedenlerin ve bunların yerine alternatif çalışma uygulanma durumlarının incelenmesinde "değişkenlerin tek tek, tür ya da miktar olarak oluşumlarının belirlenmesi amacıyla yapılan" tekil tarama modelinden faydalanılmışır. Türkçe öğretmenlerinin hazırlık çalışmalarını uygulama durumlarının cinsiyet, yaş, mesleki kıdem ve görev yaptıkları okulun bulunduğu yerleşim birimi değişkenleriyle olan ilişkisinin belirlenmesinde ise "iki ve daha çok sayıdaki değişken arasında birlikte değişim varlığını ve / veya derecesini belirlemeyi amaçlayan" ilişkisel tarama modeli kullanılmıştır (Karasar, 2012, s. 79-81).

\subsection{Evren ve Örneklem}


Bu araştırmanın çalışma evrenini Trabzon il sınırları içinde görev yapan ve 6. sınıf Türkçe dersine giren Türkçe öğretmenleri oluşturmaktadır. Çalışmanın örneklemini ise 20152016 eğitim-öğretim yılında Trabzon il sınırları içinde görev yapan ve 6. sınıf Türkçe dersine giren, basit tesadüfî örnekleme yöntemiyle seçilmiş 53 Türkçe öğretmeni oluşturmaktadır. Örnekleme ilişkin bilgiler Tablo 1'de sunulmuştur.

Tablo 1.

Katılımcılara Iliş̧kin Demografik Bilgiler

\begin{tabular}{lcc}
\hline \multicolumn{1}{c}{ Değişken } & N & \% \\
\hline Cinsiyet & 32 & 60,4 \\
Kadın & 21 & 39,6 \\
Erkek & & \\
Yaş & 16 & 30,2 \\
$21-30$ & 33 & 62,3 \\
$31-40$ & 3 & 5,7 \\
$41-50$ & 1 & 1,9 \\
$51+$ & & \\
Mesleki Kıdem & 10 & 18,9 \\
$0-5$ Yıl & 21 & 39,6 \\
$6-10$ Yıl & 18 & 34 \\
$11-15$ Yıl & 2 & 3,8 \\
$16-20$ Yıl & 2 & 3,8 \\
$21+$ & & \\
Okulun Bulunduğu Yerleşim & & 75,5 \\
Birimi & 40 & 24,5 \\
Şehir (il / İlçe) Merkezi & 13 & \\
Şehir (il /ilçe) Merkezine Uzak & & \\
Mahalle & &
\end{tabular}

Tablo 1'de araştırmaya katılan Türkçe öğretmenlerine ilişkin demografik bilgilerin dağılımı gösterilmektedir. Buna göre katılımcılardan 32 kişi $(\% 60,4)$ kadın, 21 kişi $(\% 39,6)$ erkektir. Türkçe öğretmenlerinden 16 kişi $(\% 30,2)$ 21-30 yaş aralığında, 33 kişi $(\% 62,3)$ 31-40 yaş aralığında, 3 kişi $(\% 5,7) 41-50$ yaş aralığında ve 1 kişi $(\% 1,9) 51$ yaşın üzerindedir. Mesleki kıdem bakımından katıımcılardan 10 kişi $(\% 18,9)$ 0-5 yıl aralığında, 21 kişi $(\% 39,6)$ 6-10 yıl aralığında, 18 kişi (\%34) 11-15 yıl aralığında, 2 kişi $(\% 3,8) 16-20$ yıl aralığında ve yine 2 kişi $(\% 3,8) 21$ yıl ve üzerinde öğretmenlik tecrübesine sahiptir. Türkçe öğretmenlerinden 40 kişinin $(\% 75,5)$ görev yaptığı okul şehir (il-ilçe) merkezinde yer alırken 13 öğretmenin okulu ise şehir (il-ilçe) merkezine uzak mahallelerde yer almaktadır.

Tablo 2'de, Trabzon il genelinde kullanılan Öğün Yayınları tarafından hazırlanan Ilköğretim Türkçe 6 Öğretmen Kılavuz Kitabı'ndan örneklem olarak seçilen 17 hazırlık çalışmasının ders kitabındaki dağııımıyla ilgili bilgiler sunulmuştur.

Tablo 2.

Seçilen Hazırık Çalıșmalarına ilișkin Bilgiler

\begin{tabular}{lc}
\hline Metin Adı & Seçilen Hazırlık Çalışması Sayısı \\
\hline Akşamla Gelen & 1 \\
Anadolu Adı & 2 \\
Okul & 1 \\
Atatürk'ten Anılar & 3 \\
Mustafa Kemal Atatürk & 2 \\
Eskici & 2 \\
Ben Öğretmenim Çocuklar & 1 \\
Gurbetten Mektup Var & 1 \\
Bayrağımızın Altında & 2
\end{tabular}




\subsection{Veri Toplama Araçları}

Çalışmada veri toplama aracı olarak "Kişisel Bilgi Formu" ve araştırmacılar tarafından geliştirilen "Türkçe Öğretmenlerinin 6. Sınıf Düzeyindeki Hazırlık Çalışmalarını Uygulama Durumu Anketi" kullanılmıştır.

Kişisel Bilgi Formu'nda katılımcıların demografik bilgilerini belirlemeye yönelik sorular (cinsiyet, yaş, mesleki kıdem, okulun bulunduğu yerleşim birimi) yer almaktadır. Türkçe Öğretmenlerinin 6. Sınıf Düzeyindeki Hazırlık Çalışmalarını Uygulama Durumu Anketi ise üç bölüm olarak tasarlanmıştır. Illk bölümde hazırlık çalışmalarının uygulanma durumuna, ikinci bölümde hazırlık çalışmalarının kısmen uygulanması ya da uygulanmaması durumunun gerekçelerine yönelik seçenekli maddeler mevcuttur. Üçüncü bölümde ise anket maddelerinde belirtilenlerden farklı alternatif hazırlık çalışmalarının yapılıp yapılmadığı sorulmuştur.

Anket maddeleri Kaplan (2015) tarafından hazırlanan Ilköğretim Türkçe 6 Öğretmen Kılavuz Kitabı'nda yer verilen hazırlık çalışmalarından elde edilmiştir. Anket maddeleri tespit edilirken yıllık plana göre hareket edilmiş ve sadece 2015-2016 eğitim-öğretim yılının ilk dönemine ait metinlere yönelik hazırlık çalışmaları seçilmiştir. Ayrıca sınıf içinde gerçekleştirilmesi öngörülen hazırlık çalışmaları ve öğretmen hazırlığına yönelik çalışmalar anketin madde kapsamı dışında bırakılmıştır. Toplamda 17 maddeden oluşan bu ankette hazırlık çalışmalarının uygulanmasına yönelik üçlü Likert tipi bir dereceleme (evet, kısmen, hayır) yapılmıştır.

İkinci bölümde, hazırlık çalışmalarının kısmen uygulanma veya uygulanmama gerekçelerini belirlemek üzere Türkçe öğretmenlerinin ve alan uzmanlarının görüşlerine başvurularak seçenekli maddeler geliştirilmiştir. Birden fazla işaretlemeye açık bırakılan bu seçenekler altıyla sınırlandırımıştır: "çalışmanın fazla zaman alıcı olması", "fiziksel imkânların yetersizliği", "kazanımlar için yetersiz bir çalışma olması", "çalışmanın gereksiz olması", "öğrenci seviyesinin üzerinde görülmesi" ve "diğer nedenler". Türkçe öğretmenlerinden "diğer nedenler" sütununu işaretledikleri takdirde bu nedenleri belirtmeleri istenmiştir.

Üçüncü bölümde ise Türkçe öğretmenlerinin ankette belirtilen hazırlık çalışmaları yerine alternatif hazırlık çalışmaları uygulayıp uygulamadıkları "alternatif bir hazırlık çalışması uyguladıysanız lütfen belirtiniz" ifadesiyle tespit edilmeye çalışılmıştır.

\section{4. Verilerin Analizi}

Çalışmada elde edilen veriler SPSS programı aracılı̆̆ıyla analiz edilmiştir. Hazırlık çalışmalarının uygulanma durumları incelenirken çalışmaların uygulanma düzeyine ve kısmen uygulanma veya uygulanmama nedenlerine ilişkin olarak aritmetik ortalama, frekans ve yüzde değerlerine bakılmıştır. Hazırlık çalışmalarının uygulanma durumları incelenirken evet (3), kısmen (2) ve hayır (1) puan olarak değerlendirmeye alınmıştır. Daha sonra madde genel ortalamasının altında kalan maddeler üzerine değerlendirmeler gerçekleştirilmiştir.

Hazırlık çalışmalarının kısmen uygulanma ve uygulanmama gerekçeleri analiz edilirken öncelikli olarak tüm maddelere yönelik frekans, yüzde ve aritmetik ortalama değerlerine bakılmıştır. Ardından uygulanma düzeyi madde genel ortalamasının altında kalan maddelerin kısmen uygulanma ve uygulanmama gerekçeleri ayrıca değerlendirilmiştir.

Hazırlık çalışmalarının uygulanma durumlarının farklı değişkenlerle olan ilişkisine yönelik olarak ise elde edilen verilerin analizi için hangi testlerin kullanılacağını belirlemek amacıyla verilerin normal dağılım gösterip göstermediği incelenmiştir. Normallik incelemesinde 
grup büyüklüg̈ü 50'den küçükse Shapiro-Wilks, büyükse Kolmogorov-Smirnov (K-S) testi değerlerine bakılmaktadır (Büyüköztürk, 2012, s. 42). Araştırmada grup büyüklüğü 50'den büyük olduğu için Kolmogorov-Smirnov (K-S) testi sonuçlarına bakılmış, ardından veri setinin çarpıklık ve basıklık değerleri incelenmiştir. Kolmogorov-Smirnov testinin sonucunda verilerin normal dağıım göstermediği belirlenmiştir. Buna karşılık veri setinin çarpıklık ve basıklık değerlerinin -2 ve +2 arasında yer aldığı görülmüştür. Bu değerler, verilerin normal dağııımı için kabul edilebilir düzeydedir (George ve Mallery, 2003). Bu nedenle verilerin istatistiksel analizi için bağımsız örneklem t-testi ve tek yönlü ANOVA kullanılmıştır.

\section{BULGULAR}

Bu bölümde Türkçe öğretmenlerinin hazırlık çalışmalarını uygulama durumlarına, hazırlık çalışmalarının kısmen uygulanması ya da uygulanmamasına yol açan etkenlerin neler olduğuna, alternatif hazırlık çalışmalarının uygulanma durumuna ve çeşitli değişkenlerin hazırlık çalışmalarının uygulanma durumuna etkisi üzerine elde edilen veriler tablolaştııılmış ve açıklanmıştır.

Tablo 3.

Hazırlık Çalışmalarının Uygulanma Durumları

\begin{tabular}{|c|c|c|c|c|c|c|c|}
\hline \multirow[b]{2}{*}{ Madde Kodları } & \multicolumn{2}{|c|}{ Evet } & \multicolumn{2}{|c|}{ Kısmen } & \multicolumn{2}{|c|}{ Hayır } & \multirow[b]{2}{*}{$\bar{X}$} \\
\hline & $f$ & $\%$ & $f$ & $\%$ & $f$ & $\%$ & \\
\hline M1 & 17 & 32,1 & 17 & 32,1 & 19 & 35,8 & 1,96 \\
\hline M2 & 28 & 52,8 & 17 & 32,1 & 8 & 15,1 & 2,38 \\
\hline M3 & 11 & 20,8 & 22 & 41,5 & 20 & 37,7 & 1,83 \\
\hline M4 & 24 & 45,3 & 16 & 30,2 & 13 & 24,5 & 2,21 \\
\hline M5 & 25 & 47,2 & 17 & 32,1 & 11 & 20,8 & 2,26 \\
\hline M6 & 29 & 54,7 & 17 & 32,1 & 7 & 13,2 & 2,41 \\
\hline M7 & 26 & 49,1 & 12 & 22,6 & 15 & 28,3 & 2,21 \\
\hline M8 & 12 & 22,6 & 14 & 26,4 & 27 & 50,9 & 1,72 \\
\hline M9 & 17 & 32,1 & 20 & 37,7 & 16 & 30,2 & 2,02 \\
\hline M10 & 27 & 50,9 & 15 & 28,3 & 11 & 20,8 & 2,30 \\
\hline M11 & 9 & 17 & 22 & 41,5 & 22 & 41,5 & 1,75 \\
\hline M12 & 8 & 15,1 & 11 & 20,8 & 34 & 64,2 & 1,51 \\
\hline M13 & 24 & 45,3 & 16 & 30,2 & 13 & 24,5 & 2,21 \\
\hline M14 & 26 & 49,1 & 16 & 30,2 & 11 & 20,8 & 2,28 \\
\hline M15 & 12 & 22,6 & 16 & 30,2 & 25 & 47,2 & 1,75 \\
\hline M16 & 26 & 49,1 & 17 & 32,1 & 10 & 18,9 & 2,30 \\
\hline M17 & 12 & 22,6 & 20 & 37,7 & 21 & 39,6 & 1,83 \\
\hline Ortalama & 6,28 & 37 & 5,38 & 31,6 & 5,34 & 31,4 & 2,05 \\
\hline
\end{tabular}

Tablo 3 incelendiği zaman Türkçe öğretmenlerinin hazırlık çalışmalarının \%37'sini tam olarak uyguladıklarını belirttikleri tespit edilmiştir. Hazırlık çalışmalarının kısmen uygulanma düzeyi \%31,6, uygulanmama düzeyi ise $\% 31,4$ 'tür. Hazırlık çalışmalarının uygulanma durumuna ilişkin genel madde ortalamasının 2,05 olduğu görülmektedir. Toplamda 9 madde ortalamanın üzerinde bir uygulanma düzeyine sahipken 8 maddenin ise genel ortalamanın altında uygulanma düzeyine sahip olduğu görülmüştür.

Genel madde ortalamasının üzerinde olan hazırlık çalışmaları şunlardır: "Anadolu Adı" metninin okuma bölümünde kullanılmak üzere öğrencilerin yaşadıkları sokağın, mahallenin, ilçenin veya şehrin adının nereden geldiğini araştırmalarını sağlama (M2), "Okul" metninin dinleme bölümünde kullanılmak üzere öğrencilerin bilim, sanat, spor, edebiyat vb. alanlarda tanınmış kişilere ait okul hayatıyla ilgili anılar bulmalarını sağlama (M4); "Atatürk'ten Anılar" metninde öğrencilerin farklı kaynaklardan yararlanarak fotoğraf ve resimlerle destekledikleri 
"Atatürk'ün Hayatı" konulu bir ödev hazırlamalarını sağlama (M5); "Atatürk'ten Anılar" metninin yazma bölümünde kullanılmak üzere öğrencilerin Atatürk'ün bir anısını sınıfa getirmelerini sağlama (M6); “Atatürk'ten Anılar” metninin yazma bölümünde sunulmak üzere öğrencilerin kısaltmaların ve kısaltmalara getirilen eklerin yazımı konusunda bilgi toplamalarını ve konuyla ilgili örnek bulmalarını sağlama (M7); "Eskici" metninin okuma bölümünde kullanıımak üzere öğrencilerin Refik Halit Karay'ın hayatı, sanatı ve eserleri hakkında araştırma yapmalarını sağlama (M10); "Gurbetten Mektup Var" metninin yazma bölümünde kullanılmak üzere öğrencilerin vatan sevgisini yansıtan resim veya fotoğraflar getirmelerini sağlama (M13); Öğrencilerin "Bayrağımızın Altında" metninin dinleme bölümünde kullanılmak üzere bayrak sevgisini gösteren fotoğraf ve resimler getirmelerini sağlama (M14); "Kaşağı" metninin okuma bölümünde kullanılmak üzere öğrencilerin Illköğretim Okulları İçin 100 Temel Eser'den Ömer Seyfettin'in Yalnız Efe adlı eserini çevrelerinde bulunan bir kitaplık, kütüphane, kitabevi ya da kitap fuarından temin ederek okumalarını sağlama (M16).

Genel madde ortalamasının altında olan hazırlık çalışmaları ise şunlardır: "Akşamla Gelen" metninin okuma bölümünde kullanılmak üzere öğrencilerin sınıfa akşam vaktini gösteren fotoğraflar / resimler getirmelerini sağlama (M1); "Anadolu Adı" metninin okuma bölümünde bir şiir dinletisi düzenlemek amacıyla öğrencilerin Anadolu temalı şiirler bularak bu şiirlerden en beğendiklerini ezberlemelerini sağlama (M3); "Mustafa Kemal Atatürk" metninde öğrencilerin İlköğretim Okulları İçin 100 Temel Eser'den birine yönelik haftalık okuma planı yapmalarını, okudukları kitapla ilgili duygu ve düşüncelerini yazarak kitabı bitirdikleri günden hemen sonraki derste yazdıklarını sınıfta arkadaşlarıyla paylaşmalarını sağlama (M8); "Mustafa Kemal Atatürk" metninin konuşma bölümünde kullanılmak üzere öğrencilerin Atatürk'ün kişilik özellikleri hakkında araştırma yapmalarını ve araştırmalarını destekleyecek fotoğraflar getirmelerini sağlama (M9); "Eskici” metninin okuma ve yazma bölümlerinde kullanılmak üzere öğrencilerin Türkçenin sorunları ile ilgili haberlerin yer aldığı gazete ve dergi kupürleri (makale, haber, reklam, ilan, yazı dizisi) ve bunları destekler nitelikte fotoğraf ve resim bularak sınıfa getirmelerini sağlama (M11); "Ben Öğretmenim Çocuklar" metninin okuma bölümünde kullanılmak üzere öğrencilerin kitaplık, kütüphane, kitap fuarı ya da kitabevlerinden "öğretmenlerin öğrencilerine duydukları sevgi" konusunda yazılmış bir kitap bularak okumalarını sağlama (M12); "Bayrağımızın Altında" metninin dinleme bölümünde yapılacak olan canlandırma etkinliği için belirlenen öğrenci gruplarının Halide Edip Adıvar'ın hayatı, sanatçı kişiliği ve eserleri hakkında bilgi toplamalarını, elde ettikleri bilgilerden hareketle Halide Edip Adıvar'la yapılmış hayali bir röportaj metni yazmalarını ve aralarında görev dağılımı yaparak Halide Edip Adıvar'ı ve onunla röportaj yapan muhabiri canlandırmaya hazırlanmalarını sağlama (M15); "Kaşağı" metninin okuma bölümünde yapılacak olan canlandırma etkinliği için belirlenen öğrenci gruplarının Ömer Seyfettin'in hayatı, sanatçı kişiliği ve eserleri hakkında bilgi toplamalarını, elde ettikleri bilgilerden hareketle Ömer Seyfettin'le yapılmış hayali bir röportaj metni yazmalarını ve aralarında görev dağııımı yaparak Ömer Seyfettin'i ve onunla röportaj yapan muhabiri canlandırmaya hazırlanmalarını sağlama (M17).

Tablo 4.

Hazırlık Çalışmalarının Uygulanmama veya Kısmen Uygulanma Nedenleri

\begin{tabular}{|c|c|c|c|c|c|c|c|c|c|c|c|c|}
\hline \multirow[t]{2}{*}{$\begin{array}{l}\text { Madde } \\
\text { Kodları }\end{array}$} & \multicolumn{2}{|c|}{$\begin{array}{l}\text { Fazla Zaman } \\
\text { Alıcı Olması }\end{array}$} & \multicolumn{2}{|c|}{$\begin{array}{c}\text { Fiziksel } \\
\text { İmkânların } \\
\text { Yetersizliği }\end{array}$} & \multicolumn{2}{|c|}{$\begin{array}{c}\text { Kazanımlar } \\
\text { İçin Yetersiz } \\
\text { Bir Çalışma } \\
\text { Olması }\end{array}$} & \multicolumn{2}{|c|}{$\begin{array}{c}\text { Gereksiz Bir } \\
\text { Çalışma } \\
\text { Olması }\end{array}$} & \multicolumn{2}{|c|}{$\begin{array}{l}\text { Öğrenci } \\
\text { Seviyesinin } \\
\text { Üzerinde } \\
\text { Olması }\end{array}$} & \multicolumn{2}{|c|}{ Diğer } \\
\hline & $f$ & $\%$ & $f$ & $\%$ & $f$ & $\%$ & $f$ & $\%$ & $f$ & $\%$ & $f$ & $\%$ \\
\hline M1 & 8 & 18,1 & 14 & 31,8 & 4 & 9,1 & 16 & 36,3 & 0 & 0 & 2 & 4,5 \\
\hline M2 & 15 & 53,6 & 5 & 17,9 & 2 & 7,1 & 2 & 7,1 & 3 & 10,7 & 1 & 3,6 \\
\hline M3 & 29 & 53,7 & 8 & 14,8 & 3 & 5,5 & 7 & 13 & 4 & 7,4 & 3 & 5,5 \\
\hline
\end{tabular}




\begin{tabular}{lcccccccccccc} 
M4 & 13 & 40,6 & 7 & 21,9 & 3 & 9,4 & 4 & 12,5 & 5 & 15,6 & 0 & 0 \\
M5 & 15 & 46,9 & 7 & 21,9 & 5 & 15,6 & 4 & 12,5 & 0 & 0 & 1 & 3,1 \\
M6 & 11 & 50 & 4 & 18,1 & 2 & 9,1 & 3 & 13,6 & 1 & 4,5 & 1 & 4,5 \\
M7 & 8 & 40 & 2 & 10 & 3 & 15 & 2 & 10 & 3 & 15 & 2 & 10 \\
M8 & 25 & 61 & 2 & 4,9 & 3 & 7,3 & 7 & 17 & 2 & 4,9 & 2 & 4,9 \\
M9 & 19 & 45,2 & 10 & 23,8 & 2 & 4,8 & 6 & 14,3 & 1 & 2,4 & 4 & 9,5 \\
M10 & 12 & 40 & 5 & 16,7 & 1 & 3,3 & 6 & 20 & 4 & 13,3 & 2 & 6,7 \\
M11 & 16 & 29,6 & 19 & 35,1 & 2 & 3,7 & 4 & 7,4 & 9 & 16,7 & 4 & 7,4 \\
M12 & 14 & 28,6 & 21 & 42,9 & 2 & 4,1 & 11 & 22,4 & 1 & 2 & 0 & 0 \\
M13 & 9 & 27,3 & 9 & 27,3 & 3 & 9,1 & 11 & 33,3 & 1 & 3 & 0 & 0 \\
M14 & 7 & 21,2 & 9 & 27,2 & 3 & 9,1 & 10 & 30,3 & 2 & 6,1 & 2 & 6,1 \\
M15 & 25 & 50 & 6 & 12 & 1 & 2 & 7 & 14 & 9 & 18 & 2 & 4 \\
M16 & 10 & 38,4 & 9 & 34,6 & 0 & 0 & 3 & 11,5 & 3 & 11,5 & 1 & 3,8 \\
M17 & 28 & 57,1 & 8 & 16,3 & 0 & 0 & 2 & 4,1 & 11 & 22,4 & 0 & 0 \\
Ortalama & 4,98 & 41,36 & 2,74 & 22,76 & 0,74 & 6,15 & 1,98 & 16,44 & 1,09 & 9,05 & 0,51 & 4,24 \\
\hline
\end{tabular}

Tablo 4'te görüldüğg̈ üzere hazırlık çalışmalarının uygulanmama veya kısmen uygulanma nedenlerine ilişkin olarak genel ortalama incelendiği zaman ilk sırada çalışmanın "fazla zaman alıcı olması" (\%41,36) görülmektedir. Bunu daha sonra sırasıyla "fiziksel imkânların yetersizliği"(\%22,76), "gereksiz bir çalışma olması"(\%16,44), "öğrenci seviyesinin üzerinde olması"(\%9,05), "kazanımlar için yetersiz bir çalışma olması" $(\% 6,15)$ ve "diğer nedenler" (\%4,24) takip etmektedir. Türkçe öğretmenleri, diğer nedenler arasında "6. sınıf konularının çok yoğun olması sebebiyle bu tür hazırlık çalışmalarına eğilememe, çalışmanın öğrencilerin ilgisini çekmeyeceği düşüncesi, öğrencilerin isteksizliği, kütüphanelerin yetersizliği" şeklinde kodlanabilecek gerekçeler belirtmişlerdir.

Uygulanma düzeyi genel ortalamanın altında yer alan etkinliklerde ise (M1, M3, M8, M9, M11, M12, M15, M17) hazırlık çalışmalarının uygulanmama veya kısmen uygulanma gerekçelerine ilişkin yüzde değerleri şu şekildedir: Fazla zaman alıcı olması $(\% 42,8)$, fiziksel imkânların yetersizliği (\%23), gereksiz bir çalışma olması $(\% 15,7)$, öğrenci seviyesinin üzerinde olması $(\% 9,7)$, kazanımlar için yetersiz bir çalışma olması $(\% 4,4)$, diğer nedenler $(\% 4,4)$. Görüldüğü üzere genel ortalamanın altında uygulanma durumu olan hazırlık çalışmaları, tablodaki genel ortalamaya ait yüzde değerleriyle yaklaşık olarak benzer sonuçlar vermektedir. Bu bulguların yanı sıra uygulanma düzeyi genel ortalamanın altında kalan bu maddelerin 5 tanesinde (M3, M8, M9, M15, M17) çalışmanın "fazla zaman alıcı olması", uygulanmama veya kısmen uygulanmaya yönelik ilk sıradaki neden olarak gösterilirken 3 madde de (M1, M11, M12) çalışmanın uygulanmasını sağlayacak "fiziksel imkânların yetersizliği" ilk gerekçe olarak belirtilmiştir.

Tablo 5.

Alternatif Hazırık Çalışması Uygulanma Durumu

\begin{tabular}{lccc} 
Alternatif Hazırlık Çalışması Uygulanma Durumu & $\begin{array}{c}\text { Çalışmaları Kısmen } \\
\text { Uygulayan ve } \\
\text { Uygulamayan } \\
\text { Öğretmenler }\end{array}$ & Alternatif Çalışma Uygulayan Öğretmenler \\
\hline M1 & $\mathbf{f}$ & $\mathbf{f}$ & $\%$ \\
M2 & 36 & 1 & 2,78 \\
M3 & 25 & 3 & 12 \\
M4 & 42 & 2 & 4,76 \\
M5 & 29 & 1 & 3,45 \\
M6 & 28 & 2 & 7,14 \\
M7 & 24 & 0 & - \\
M8 & 27 & 0 & - \\
& 41 & 4 & 9,76
\end{tabular}




\begin{tabular}{lccc} 
M9 & 36 & 1 & 2,78 \\
M10 & 26 & 0 & - \\
M11 & 44 & 3 & 6,81 \\
M12 & 45 & 3 & 6,67 \\
M13 & 29 & 1 & 3,45 \\
M14 & 27 & 0 & - \\
M15 & 41 & 0 & - \\
M16 & 27 & 3 & 11,1 \\
M17 & 41 & 0 & - \\
Ortalama & 33,4 & 1,41 & 4,22 \\
\hline
\end{tabular}

Tablo 5 incelendiği zaman Türkçe öğretmenleri tarafından kısmen uygulanan veya uygulanmayan 17 hazırlık çalışmasının 11 tanesinde alternatif hazırlık çalışması uygulandığı görülmektedir. En yüksek oranda $M 2$ hazırlık çalışmasının yerine alternatif hazırlık çalışması uygulanırken M6, M7, M10, M14, M15, M17 hazırlık çalışmaları yerine herhangi bir alternatif çalışma uygulanmadığı ortaya çıkmıştır. Hazırlık çalışmalarının kısmen uyguladığını ya da uygulamadığını belirten Türkçe öğretmenleri içinde bu çalışmaların yerine alternatif hazırlık çalışması uygulayan Türkçe öğretmenlerinin oranı \%4,22'dir. Uygulanma düzeyi genel madde ortalamasının altında kalan çalışmalarda (M1, M3, M8, M9, M11, M12, M15, M17) alternatif hazırlık çalışması uygulayan öğretmenlerin oranı ise $\% 4,29$ olarak tespit edilmiştir.

Tablo 6.

Hazırlık Çalışmalarını Uygulama Durumunun Cinsiyet Değişkenine Göre Bağımsız Örneklem T-Testi Sonuçları

\begin{tabular}{llccccc}
\hline Cinsiyet & $\mathbf{N}$ & $\bar{X}$ & S & Sd & t & p \\
\hline Kadın & 32 & 2 &, 44 & 51 & $-1,147$ &, 257 \\
Erkek & 21 & 2,14 &, 35 & & & \\
\hline$* p<0.05$ & & & & & &
\end{tabular}

Tablo 6'da erkek Türkçe öğretmenlerinin hazırlık çalışmalarını uygulama durumu madde puan ortalamalarının $(\bar{X}=2,14)$, kadın Türkçe öğretmenlerine göre $(\bar{X}=2)$ daha yüksek olduğu görülmektedir. Bağımsız örneklem t-testi sonucunda Türkçe öğretmenlerinin hazırlık çalışmalarını uygulama durumu anketinden aldıkları puanların cinsiyete göre anlamlı bir farklılık göstermediği görülmüştür $\left[\mathrm{t}_{(53)}=-1,147, \mathrm{p}>\right.$.05].

Tablo 7.

Hazırlık Çalışmalarını Uygulama Durumunun Yaş Değişkenine Göre Tek Yönlü ANOVA Testi Sonuçları

\begin{tabular}{lcccc}
\hline Yaş Düzeyi & $\mathbf{N}$ & $\bar{X}$ & $\mathbf{F}$ & $\mathbf{p}$ \\
\hline $21-30$ & 16 & 2,03 & & \\
$31-40$ & 33 & 2,04 &, 784 &, 508 \\
$41-50$ & 3 & 2,41 & & \\
$51+$ & 1 & 2,06 & & \\
\hline
\end{tabular}

Tablo 7 incelendiği zaman Tek Yönlü ANOVA sonucuna göre Türkçe öğretmenlerinin hazırlık çalışmalarını uygulama durumlarının yaş değişkenine göre anlamlı bir farklılık göstermediği ortaya çıkmaktadır ( $\mathrm{F}=.784 ; \mathrm{p}>$.05). Türkçe öğretmenlerinin hazırlık çalışmalarını uygulama durumları puan ortalamalarına bakıldığında ise en yüksek ortalamaya sahip yaş grubunun 4150 yaş aralığındaki Türkçe öğretmenleri $(\bar{X}=2,41)$, en düşük ortalamaya ise 21-30 yaş arasındaki Türkçe öğretmenlerinin ( $\bar{X}=2,03$ ) sahip olduğu görülmüştür. 
Tablo 8.

Hazırlık Çalışmalarını Uygulama Durumunun Mesleki Kıdem Değişkenine Göre Tek Yönlü ANOVA Testi Sonuçları

\begin{tabular}{lcccc}
$\begin{array}{l}\text { Mesleki Kıdem } \\
\text { Düzeyi }\end{array}$ & $\mathbf{N}$ & $\bar{X}$ & $\mathbf{F}$ & $\mathbf{p}$ \\
\hline $0-5 Y_{I} I$ & 10 & 2,02 &, 982 &, 426 \\
$6-10$ Yıl & 21 & 2,10 & & \\
$11-15$ Yıl & 18 & 1,96 & & \\
$16-20$ Yıl & 2 & 2,53 & & \\
21 Yıl ve Üzeri & 2 & 2,12 & & \\
\hline
\end{tabular}

Tablo 8'de görüldüğü üzere Türkçe öğretmenlerinin hazırlık çalışmalarını uygulama durumlarının mesleki kıdem değişkenine göre anlamlı bir farklılık göstermediği ortaya çıkmaktadır ( $F=.982 ; p>.05)$. Puan ortalamalarına bakıldığında ise en yüksek ortalamaya sahip mesleki kıdem grubunun 16-20 yıl arasında görev yapmakta olan Türkçe öğretmenleri $(\bar{X}=$ $2,53)$, en düşük ortalamaya sahip grubun ise 11-15 yıl arasında görev yapmakta olan Türkçe öğretmenleri ( $\bar{X}=1,96)$ olduğu görülmüştür.

Tablo 9.

Hazırlık Çalışmalarını Uygulama Durumunun Okulun Bulunduğu Yerleşim Birimi Değişkenine Göre Bağımsız Örneklem T-Testi Sonuçları

\begin{tabular}{|c|c|c|c|c|c|c|}
\hline $\begin{array}{l}\text { Yerleşim } \\
\text { Birimi }\end{array}$ & $\mathbf{N}$ & $\bar{X}$ & $\mathbf{S}$ & Sd & $t$ & $p$ \\
\hline Şehir & 40 & 2,08 & ,40 & & & \\
\hline Merkezi & & & & 51 & 699 & 488 \\
\hline $\begin{array}{l}\text { Uzak } \\
\text { Mahalle }\end{array}$ & 13 & 1,99 & ,46 & & & \\
\hline
\end{tabular}

Tablo 9 incelendiği zaman şehir merkezinde (il ve ilçe merkezleri) görev yapan Türkçe öğretmenlerinin hazırlık çalışmalarını uygulama durumu madde puan ortalamalarının $(\bar{X}=$ 2,08), şehir merkezlerine uzak mahallelerde görev yapan Türkçe öğretmenlerine göre $(\bar{X}=$ $1,99)$ daha yüksek olduğu görülmektedir. Bağımsız örneklem t-testi sonucunda Türkçe öğretmenlerinin hazırlık çalışmalarını uygulama durumu anketinden aldıkları puanların görev yaptıkları yerleşim birimine göre anlamlı bir farklılık göstermediği görülmüştür $\left[\mathrm{t}_{(53)}=-, 699\right.$, p>.05].

\section{TARTIŞMA, SONUÇ VE ÖNERILER}

Araştırma sonucunda Türkçe öğretmenlerinin 6. sınıf Türkçe dersi öğretmen kılavuz kitabında yer alan hazırlık çalışmalarını tam olarak uygulama düzeylerinin \%37 olduğu ortaya çıkmışır. Bu çalışmalar, \%31,6 oranında kısmen uygulanırken \%31,4 oranında ise uygulanmamaktadır. Hazırlık çalışmalarının kısmen uygulanma ya da uygulanmamasına yönelik gerekçeler arasında ilk sırada çalışmanın fazla zaman alıcı $(\% 41,36)$ olması gösterilmiştir. Bu gerekçeyi daha sonra sırasıyla fiziksel imkânların yetersiz olması (\%22,76), çalışmanın gereksiz olması $(\% 16,44)$, çalışmanın öğrenci seviyesinin üzerinde olması $(\% 9,05)$, çalışmanın kazanımlar için yetersiz olması $(\% 6,15)$ ve diğer nedenler $(\% 4,24)$ izlemektedir. Kısmen uyguladıkları ya da uygulamadıkları hazırlık çalışmalarının yerine alternatif hazırlık çalışması gerçekleştiren Türkçe öğretmenlerinin oranı \%4,22'dir. Türkçe öğretmenlerinin hazırlık çalışmalarını uygulama durumlarıyla cinsiyetleri, yaşları, mesleki kıdemleri ve görev yaptıkları okulun bulunduğu yerleşim birimi değişkenleri arasında anlamlı bir ilişki bulunamamıştır. 
Hazırlık çalışmalarının kısmen uygulanması ya da uygulanmamasına yönelik en sık gösterilen neden olan çalışmaların fazla zaman alıcı olması, Türkçe Dersi Öğretim Programı́yla ilgili yapılan farklı çalışmalarda da ortaya çıkmaktadır. Susar Kırmızı ve Akkaya'nın (2009) sınıf öğretmenlerinin Türkçe Dersi Öğretim Programı ile ilgili yaşadıkları sorunları belirlemeye yönelik gerçekleştirdikleri araştırmalarında, öğretmenlerin ilk sırada programla ilgili çalışmaları yaparken zaman yetmediğini ifade ettiklerini bulgulamıştır. Bu noktada, hazırlık çalışmaları, uygulamada tek başına zaman alıcı olabileceği gibi, diğer öğretim-öğrenme aşamalarındaki etkinliklerin zaman bakımından kısıtlayıcı görülmesi nedeniyle göreceli olarak daha fazla zaman alıcı olarak da düşünülmüş olabilir.

Karadüz (2010), ilköğretim 6-8. sınıflardaki Türkçe dersi öğrenme ve öğretme sürecinin yapılandırmacı öğrenme anlayışına ne ölçüde uygun olduğunu gözlem ve öğretmen görüşlerine dayalı olarak belirlediği çalışmasında Türkçe öğretmenlerinin derse hazırlık kapsamında çevre şartlarını dikkate alan ödevler verdiklerini belirlemiştir. Hazırlık çalışmalarının uygulanmaması ya da kısmen uygulanmasına gösterilen nedenler arasında ikinci sırada yer alan fiziksel imkânların yetersizliği $(\% 22,76)$ bu bulguyla ilişkili düşünülebilir. Fiziksel imkânlar / çevre şartları, öğretmen kılavuz kitabındaki hazırlık çalışmalarının uygulanma durumu üzerinde önemli ölçüde etkili görünmektedir. Fiziksel imkânlar / çevre şartları uygun değilse Türkçe öğretmenleri, hazırlık çalışmalarını uygulamama ya da kısmen uygulama yoluna gitmektedir.

Araştırmada ortaya çıkan uygulanmayan ya da kısmen uygulanan hazırlık çalışmaları yerine alternatif hazırlık çalışması gerçekleştiren Türkçe öğretmenlerinin \%4,22 oranında olması, Karadüz'ün (2010) Türkçe öğretmenlerinin hazırlık çalışmalarını çoğunlukla kılavuz kitapta yer alan etkinliklerle yürüttüklerini belirlediği bulguyu destekler görünmektedir. Buradan Türkçe öğretmenlerinin nadiren kılavuz kitabın dışına çıkarak yeni öğrenme alanlarıyla ilgili hazırlık çalışması uyguladıkları sonucuna varılabilir.

Hazırlık çalışmalarının uygulanmaması ya da kısmen uygulanmasında fiziksel imkânların yetersizliğinin önemli rol oynadığının ortaya çıkmasına rağmen farklı çevresel imkânların bulunduğu düşünülen yerleşim birimi değişkenin hazırlık çalışmalarının uygulanma durumunda anlamlı fark oluşturmadığı görülmektedir. Bu durum, çalışmanın örneklem sayısının görece küçüklüğü ve yerleşim birimi değişkeninin sadece şehir (il / ilçe) merkezleri ve şehir merkezlerine uzak mahalleler şeklinde ayrılmasından kaynaklandığı düşünülebilir. Örneklem büyüklüğünün artırılması ve yerleşim birimi değişkenin daha özelleştirilerek sunulması (örneğin şehir merkezi olsun ya da olmasın sosyoekonomik ayrımların da gözetilmesi gibi) daha farklı sonuçlar ortaya çıkarabilir.

Araştırmanın sonuçlarına dayalı olarak aşağıdaki önerilerde bulunulmuştur:

- Türkçe dersi öğretmen kılavuz kitaplarındaki hazırlık çalışmalarının uygulanmasına ayrılacak zamanın diğer öğrenim-öğretim aşamalarına ayrılması gereken süreyle dengeli olmasını sağlamak amacıyla Türkçe derslerinde zaman yönetimine ilişkin pilot çalışmalar gerçekleştirilebilir. Çalışmalardan elde edilecek veriler, hazırlık çalışmalarının öğrenim-öğretim sürecinin diğer aşamalarıyla zamanın işlevsel kullanımı bakımından daha uyumlu bir duruma getirilmesi için kullanılabilir.

- Okulların sahip olduğu farklı fiziksel / çevresel imkânlar göz önünde tutularak kılavuz kitaplarda aynı öğrenme alanına yönelik asıl hazırlık çalışmalarıyla beraber alternatif hazırlık çalışmalarına yer verilebilir. 


\section{KAYNAKLAR}

Arslan, A. (2009). Yapılandırmacı öğrenme yaklaşımı ve Türkçe öğretimi. Atatürk Üniversitesi Sosyal Bilimler Enstitüsü Dergisi, 13 (1), 143-154.

Bloom, B. S. (1998). Insan nitelikleri ve okulda öğrenme (Çev. Durmuş Ali Özçelik). İstanbul: MEB.

Büyüköztürk, Ş. (2012). Sosyal bilimler için veri analizi (17. Baskı). Ankara: Pegem Akademi.

Dochy, F., Segers, M., \& Buehl, M. (1999). The Relation between assessment practices and outcomes of studies: The case of research on prior knowledge. Review of Educational Research, 69 (2), 147-188.

Fisher, D., Frey, N. \& Lapp, D. (2012). Building and activating students' background knowledge: It's what they already know that counts. Middle School Journal, 43 (3), 22-31.

George, D. \& Mallery, P. (2003). SPSS for Windows step by step a simple guide and reference (4th Ed.). Boston: Allyn \& Bacon.

Güneş, F. (2007). Türkçe öğretimi ve zihinsel yapılandırma. Ankara: Nobel.

Güneş, F. (2009). Türkçe öğretiminde günümüz gelişmeleri ve yapılandırıcı yaklaşım. Mustafa Kemal Üniversitesi Sosyal Bilimler Enstitüsü Dergisi, 6 (11), 1-21.

Işık, R. ve Erdem, i. (2016). Türkçe öğretiminde karşılaşılan sorunların öğretmen görüşlerine göre belirlenmesi (Muş ili örneği). Turkish Studies, 11 (3), 1309-1332.

Kaplan, F. (2015). Ilköğretim Türkçe 6 öğretmen kılavuz kitabı. Ankara: Öğün Yayınları.

Karadüz, A. (2010). Yapılandırmacı paradigma bağlamında Türkçe derslerinde öğrenme ortamları. Mustafa Kemal Üniversitesi Sosyal Bilimler Enstitüsü Dergisi, 7 (14), 135-154.

Karasar, N. (2012). Bilimsel araştırma yöntemi (24. Basım). Ankara: Nobel.

Müller-Kalthoff, T. \& Möller, J. (2006). Browsing while reading: effects of instructional design and learners' prior knowledge. ALT-J Research in Learning Technology, 14 (2), 183-198.

Onan, B. (2012). Türkçenin ana dili olarak öğretiminde bilgi işleme süreci. Mersin Üniversitesi Eğitim Fakültesi Dergisi, 8 (1), 96-113.

Örge Yaşar, F. (2011). İlköğretim ikinci kademe VII. sınıf Türkçe ders kitabında "doğa ve evren" temasına yönelik hazırlık çalışmalarında bilmecelerden yararlanma üzerine bir çalışma. Çukurova Üniversitesi Eğitim Fakültesi Dergisi, 40 (1), 114-119.

Susar Kırmızı, F. ve Akkaya, N. (2009). Türkçe öğretimi programında yaşanan sorunlara ilişkin öğretmen görüşleri. Pamukkale Üniversitesi Eğitim Fakültesi Dergisi, 25 (1), 42-54.

Yanpar Şahin, T. (1998). Ilköğretim sosyal bilgiler ve matematik dersinde çeşitli değişkenlerin öğrenme düzeyini yordama gücü. Hacettepe Üniversitesi Eğitim Fakültesi Dergisi, 14, 4553. 


\section{SUMMARY}

With the primary school (6th, 7th and 8th grades) Turkish curriculum based on a constructivist teaching approach, students are expected to effectively process information obtained in a learning environment through a set of mental processes and structure it in mind. For the realization of meaningful learning, student's new information must interact with their prior knowledge and be made permanent through various mental activities. However, in today's world of exponentially increasing information, there is an increasing differentiation between students' prior knowledge for a wide range of reasons. This has become an important factor affecting teaching-learning processes. In this regard, the functionality of preparatory activities for new learning domains in different course contents is considered to have a role in the differentiation between of prior knowledge. Therefore, it is of growing importance to identify to what extent preparatory activities within course contents are implemented in the teaching process and what problems lead to the inadequate implementation of preparatory activities. Thus, a major problem with the better effectiveness of preparatory activities is likely to be solved. To this end, the present study aims to examine the implementation of preparatory activities in Turkish course books and to reveal the causes of the problems in the completion of such activities.

The research population involves Turkish teachers working in Province Trabzon and teaching Turkish class to 6th-grade students. The research sample consists of 53 Turkish teachers selected by simple random sampling method who serve in Trabzon and teach Turkish class to 6th-graders in the school year 2015-2016.

Data was collected using a "Personal Information Form" and the "Turkish Teachers' Implementation of 6th-Grade Preparatory Activities Survey" developed by researchers. The Personal Information Form contains questions to identify the demographics of the respondents (gender, age, seniority, the residential area of the school). The Turkish Teachers' Implementation of 6th-Grade Preparatory Activities Survey was designed in three parts. The first part involves multiple choice items for the implementation of preparatory activities and the second part for the reasons behind not implementing or partially implementing preparatory activities. The third part enquires whether or not alternative preparatory activities other than those presented in the survey are done.

The survey items were drawn from Teacher's Guide Book of $6^{\text {th }}$-Grade Turkish Course designed by Kaplan (2015). The survey items were also determined based on the annual curriculum in such a way to involve only preparatory activities for the texts taught in the first semester of the 2015-2016 school year. Classroom activities and teacher preparation activities were also excluded from the scope of the survey. The survey is composed of 17 items to be rated on a three-point Likert-type scale. In the second part of the survey, multiple choice items were developed based on the views of Turkish teachers and field experts in order to determine the reasons for not implementing or partially implementing preparatory activities. These multiple-mark survey items include six choices as follows: "time-consuming nature of activities", "lack of physical facilities", "inadequacy of activities for outcomes", "redundancy of activities", "activities considered to be above the students' level" and "other reasons". Turkish teachers are asked to specify their reasons when they mark the column "other reasons". The third part enquires whether or not Turkish teachers implement alternative preparatory activities in lieu of those presented in the survey and includes the statement "Please indicate if you have implemented any alternative preparation activity".

The research results demonstrated that $37 \%$ of the Turkish teachers thoroughly completed the preparatory activities included in the teacher's guide book of $6^{\text {th }}$-grade Turkish course. These activities were partially implemented at a rate of $31.6 \%$ and not implemented at a rate of $31.4 \%$. The primary reason expressed by the teachers for not implementing or partial implementing preparatory activities was the time-consuming nature of such activities $(41.36 \%)$. It was followed by lack of physical facilities (22.76\%), redundancy of activities (16.44\%), activities considered to be above the students' level (9.5\%), inadequacy of activities for outcomes (6.15\%) and other reasons (4.24\%), respectively. $4.22 \%$ of the Turkish teachers did alternative preparatory activities in lieu of not implemented preparatory activities. No significant relationship was found between Turkish teachers' implementation of preparatory activities and the variables including gender, age, professional seniority and the residential area of the school. 